Article

\title{
A cross-sectional analysis of snacking habits, eating habits, physical activity, and indicators of obesity among high school students in Jakarta, Indonesia
}

\author{
Intan Lisetyaningrum, ${ }^{1}$ Hening Pujasari, ${ }^{2}$ Kuntarti $^{2}$ \\ ${ }^{1}$ Faculty of Nursing, Universitas Indonesia, Depok, West Java; ${ }^{2}$ Department of Basic Science and Fundamentals \\ of Nursing, Faculty of Nursing, Universitas Indonesia, Depok, West Java, Indonesia
}

\begin{abstract}
Background: Changes in the lifestyle and eating habits of people in large cities in Indonesia have increased the risk of obesity. In Indonesia, the prevalence of obesity in adolescents increased from $1.6 \%$ in 2013 to $4.0 \%$ in 2018 ; in Jakarta, it increased from $4.2 \%$ in 2013 to $8.3 \%$ in 2018 . Obesity is closely related to health behavior in adolescence, and it is a risk factor for the occurrence of non-communicable diseases (NCDs). This study aimed to describe the snacking habits, eating habits, physical activity, and indicators of obesity among adolescents in Jakarta.

Design and Methods: This study used a cross-sectional design involving $170,10^{\text {th }}-12^{\text {th }}$ grade public high school students in Jakarta Province, recruited using purposive sampling technique. Using standardized instruments, the following surveys were delivered online: The Beverage and Snack Questionnaire, the Eating Habits Questionnaire, and the Youth Risk Behavior Survey Questionnaire (Q78). The Chi-squared test was used to determine the correlation between the study's variables.

Results: The majority of the 170 respondents were female $(81.2 \%)$. Among the respondents, $11.2 \%$ were obese and $6.5 \%$ were overweight. Of the 170 respondents $52.4 \%$ had the habit of snacking, $64.1 \%$ had healthy eating habits, $73.5 \%$ engaged in physical activity $\leq 3$ days/week, $79.4 \%$ watched TV $<3$ hours/day, and $61.2 \%$ played video games and spent time on computers $\geq 3$ hours/day. The bivariate analysis results showed that there was no significant relationship between snacking habits, eating habits, and physical activity with indicators of obesity $(\mathrm{p}>0.05)$.

Conclusions: In general, the respondents in our study were found to have a healthy lifestyle, thus helping to prevent the development of an NCD. However, a number of the respondents were overweight and obese.
\end{abstract}

\section{Introduction}

Obesity has become one of the most serious public health challenges of the $21^{\text {st }}$ century. Previously, obesity was often associated with high-income countries; currently, it is also found in low- and middle-income countries. ${ }^{1}$

Recently, changes in the lifestyle and dietary habits of people living in large cities in Indonesia have increased of prevalence of obesity. $^{2}$ According to Indonesian Basic Health Research, in Indonesia, the prevalence of obesity among adolescents aged 1618 years increased from $1.6 \%$ in 2013 to $4.0 \%$ in 2018 ; specifically, in Jakarta, the prevalence increased from $4.2 \%$ in 2013 to $8.3 \%$ in 2018. DKI Jakarta has become the province with the highest prevalence of obesity in Indonesia. ${ }^{3}$

Obesity is one of the risk factors for non-communicable diseases (NCDs). ${ }^{2,4}$ In general, the health consequences of NCDs caused by obesity include cardiovascular disease especially heart disease and stroke), diabetes, musculoskeletal disorders, and cancer. ${ }^{1}$

Obesity is closely related to adolescents' health behavior. During adolescence, teenagers are prone to nutritional vulnerability; thus, this age group has a high risk of obesity. This is due of lifestyle changes, such as the lack of physical activity and eating or snacking habits. ${ }^{5}$

In U.S. snacking habits in schoolchildren increased from $74 \%$ in $1977-1978$ to $98 \%$ in $2003-2006 .{ }^{6}$ Snacking habits with high energy intake and snacks consumed in large quantities will significantly increase the risk of obesity. Eating habits have also become a nutritional problem in adolescents. Uncontrolled eating that has become a habit might lead to cause obesity. ${ }^{6}$

In addition to excess caloric intake, lack of exercise or low physical activity is a primary factor that increases the risk of obesity. Lack of physical activity is also a risk factor for chronic diseases, especially coronary heart disease. ${ }^{7}$

Clinically, an excessive amount of body fat is bad for a person's health. An obesity indicator, such as body mass index (BMI), is the most common parameter for determining an individual's obesity status. ${ }^{8} \mathrm{BMI}$ is an anthropometric measurement calculated by dividing body mass in kilograms by body height in meters squared $\left(\mathrm{BMI}=\mathrm{kg} / \mathrm{m}^{2}\right)$; the result is classified or grouped based on predetermined categories.

Significance for public health

Obesity is closely related to health behavior in adolescents, which is also a risk factor for non-communicable diseases (NCDs) such as cardiovascular disease (especially heart disease and stroke), diabetes, musculoskeletal disorders, and cancer. The emergence of this non-infectious disease is one of the health implications that can occur to someone in the future because of current health behavior. Therefore, obesity that occurs in adolescence needs to be considered, because obesity that occurs in adolescents will continue into adulthood and will be difficult to overcome conventionally (diet and exercise). With this research, it is hoped that it can become a reference material for the community, educational institutions, and the government to optimize programs on how to choose food and educate health behaviors to reduce excess weight in adolescents. 
Measuring risk of obesity is an important step to prevent obesity. However, it is not the only step that should be taken. Identifying and describing factors that could lead to obesity such as snacking habits, eating habits, and physical inactivity are also necessary especially in DKI Jakarta. Identifying and describing factors of obesity such as mentioned is crucial in DKI Jakarta, which has the highest prevalence of obesity in Indonesia. Analysis of those factors will help to identify the contributions of each factor to obesity. Therefore, a specific action to modify the factors can be taken in order to decrease the prevalence of obesity in DKI Jakarta.

\section{Design and Methods}

This study used a cross-sectional design. Purposive sampling was used; thus, the respondents were selected based on the inclusion criteria and research objectives. The study's inclusion criteria were: $10^{\text {th }}-12^{\text {th }}$ grade students, aged $15-18$ years that were willing to participate. The data were collected using questionnaires, which were distributed online. The Chi-squared test was used to examine the correlation between the independent and dependent variables. The sample size was determined using the Lemeshow formula, as follows:

$$
\begin{gathered}
n=\frac{Z^{2} p q}{d^{2}} \\
n=\frac{\left(1.96^{2}\right) \times 0.083 \times 0.917}{(0.05)^{2}} \\
n=\frac{0.292}{0.0025} \\
n=116.8=117
\end{gathered}
$$

Based on the result from the calculation, this study should include a minimum of 117 respondents. Nevertheless, in order to anticipate some unintended things, such as incomplete questionnaires or participant dropout, the researcher added $10 \%$ to the minimal sample size. The following formula was used to correct the sample size:

$$
\begin{gathered}
n^{\prime}=\frac{n}{1-f} \\
n^{\prime}=\frac{117}{1-0.1} \\
n^{\prime}=130
\end{gathered}
$$

Therefore, after being corrected and rounded, the minimum sample size of this study was 130 respondents. However, in this study, a final sample of 170 students was obtained by filling out an online questionnaire.

This study used three independent variables (snacking habits, eating habits, and physical activity) and one dependent variable (obesity indicator/BMI). The Beverage and Snack Questionnaire (BSQ) was used as the snacking habits variable. The Eating Habits Questionnaire was used for the eating habits variable. The Youth Risk Behavior Survey (YRBS) Q78 was used for the physical activity variable. BMI measurement was used for the obesity indicator.

The reliability of BSQ has been proven decent in previous research. The coefficients ranged from $\mathrm{r}=0.72$ and $\mathrm{r}=0.74$ for beverages and snacks, also $\mathrm{r}=0.82$ for fruits and vegetable. ${ }^{9}$ In addition, the coefficients for food consumed at school are $r=0.69$ to 0.71 and food consumed away from school are $r=0.63$ to 0.70 . The validity coefficients for the 19 individual food items ranged from $\mathrm{r}=0.69$ to 0.71 . This shows that BSQ is a proper questionnaire to use in order to measure snacking habits variable. The YRBS also has decent reliability and validity. Items related to tobacco use have mean kappa $=68.8 \%$, items related to unintentional injuries and violence have mean kappa $=59.9 \%$, items related to dietary behaviors have mean kappa $=50.0 \%$, and items related to physical activity have mean kappa $=55.2 \%$. This proves that YRBS is a proper instrument to measure physical activity variable.

\section{Results}

The data distribution of the respondents' age showed that the average age of the respondents was 16.51 years (Table 1). Then, the majority of the 170 respondents were female (81.2\%). Among the respondents, $11.2 \%$ were obese and $6.5 \%$ were overweight. Of the 170 respondents, $52.4 \%$ had the habit of snacking, $64.1 \%$ had healthy eating habits, $73.5 \%$ engaged in physical activity $\leq 3$ days/week, $79.4 \%$ watched TV $<3$ hours/day, and $61.2 \%$ played video games and spent time on computers $\geq 3$ hours/day (Table 2 ). Based on the bivariate analysis between snacking habits and BMI using the Chi-squared test, no significant correlation was found between snacking habits and BMI in senior high school adolescents in Jakarta $(\mathrm{p}=0.62 ; \alpha=0.05)$ with odds ratio (OR) $(95 \% \mathrm{CI})$ $=1.31(0.59-2.90)$ (Table 3$)$. The analysis results indicated that there was no significant correlation between eating habits and BMI $(\mathrm{p}=0.11 ; \alpha=0.05)$ with OR $(95 \% \mathrm{CI})=0.48(0.22-1.08)$ (Table 4). The bivariate analysis results for physical activity and BMI showed that there was no significant correlation between these two variables $(\mathrm{p}=0.79 ; \alpha=0.05)$ and $\mathrm{OR}(95 \% \mathrm{CI})=1.23(0.52-2.94)$ (Table 5).

\section{Discussion}

In this study, the mean age was 16 years. This study's findings are in line with the results reported by Sugiatmi and Handayani in a study on middle- and late-adolescence (15-18 years). ${ }^{2}$ Another study conducted by Kurdanti et al. also included adolescents aged 15-18 years. This is because people aged $10-18$ years are prone to nutritional vulnerability and belong to the age group that is at risk of obesity. ${ }^{5}$

In addition to age, the present study also reported results based on the respondents' sex and school grade level. The findings showed that there were more female respondents than male respondents. This might be because the questionnaires were conducted and distributed online, and both males and females could respond if they met the study's inclusion criteria. The findings are also comparable to the data on senior high school students in Jakarta, which showed that there are 87,655 female students and 75,799 male students. ${ }^{10}$

Furthermore, most of the study respondents were $10^{\text {th }}$ grade students. This study was conducted on senior high school students in the $10^{\text {th }}, 11^{\text {th }}$, and $12^{\text {th }}$ grades who were estimated to be $15-18$ -

Table 1. Respondent distribution based on age $(n=170)$.

\begin{tabular}{lccccc} 
Variable & Mean & Median & SD & Min-Max & CI $95 \%$ \\
Age & 16.51 & 16 & 0.937 & $15-18$ & $16.37-16.65$ \\
\hline
\end{tabular}


years-old (classified as middle- and late-adolescence).

Based on the BMI results, $17.6 \%$ of the respondents were classified as obese. Several factors, such as age, sex, snacking habits, eating habits, and physical activity, might affect their BMI. ${ }^{5}$ Fayasari et al. stated that BMI was significantly influenced by food supply and the consumption of snacks and sweet drinks, and it was specifically associated with the increase in obesity. ${ }^{11}$

Snacking habits influence BMI. The finding related to snacking habits showed that $52.4 \%$ of the respondents indicated that they rarely snacked. Excessive snack consumption (or eating large portions) will increase the risk of obesity. In Indonesia, it is common to find snacks made of high energy ingredients such as processed foods, saturated fat, sugar, and salt, but the consumption of snacks containing vegetables and fruits tend to be less. The excessive intake of these kinds of snacks, if it is not accompanied by an adequate level of physical activity, will increase the risk of obesity in children. ${ }^{6}$

Eating habits is another factor that influences BMI. The findings revealed that most of the respondents $(64.1 \%)$ had healthy eating habits. This percentage is similar to the results reported by Benazeera and Chauhan, ${ }^{12}$ who found that most of the adolescents $(69.3 \%)$ in their study had healthy eating habits. Puspadewi and Briawan also found that most of the respondents $(57.5 \%)$ had good eating habits. ${ }^{13}$ Thamrin et al. also showed that $63.3 \%$ of adolescents had good eating habits. ${ }^{14}$

The present study also found that $35.9 \%$ of the respondents had unhealthy eating habits. This prevalence was lower than the result reported by Puspadewi and Briawan who found that $42.5 \%$ of their subjects indicated having unhealthy eating habits. ${ }^{13}$ An unhealthy eating habit in adolescents is one of factors that might increase the risks for diseases or health problems when they become adults.

In addition to snacking and eating habits, physical activity also contributed to BMI. Kurdanti et al. stated that sex and the lack of physical activity are the factors that contribute to changes in ener- gy balance, which can lead to obesity. ${ }^{5}$ Moreover, excessive food intake that is not balanced with physical activity will increase the risk of fat accumulation and cause obesity. ${ }^{15}$ In the present study, the univariate analysis showed that $73.5 \%$ of the respondents engaged in physical activity $\leq 3$ days/week. Lack of activity could possibly be one of the main causes for the recent increase in obesity in adolescents.

Watching TV and playing computer games are types of sedentary behavior that can potentially cause obesity. When people frequently engage in activities, such as sitting for a long period of time, watching TV, or using the computer for hours, it could result in engaging in less physical activity, which indirectly leads to excess body weight. In the present study, most of the respondents (79.4\%) watched TV $<3$ hours/day on school days, but they played video games or spent time on the computer for $\geq 3$ hours/day $(61.2 \%)$ on school days. In addition to excess caloric intake, a sedentary lifestyle followed by a lack of physical activity is one of the main factors contributing to the risk of obesity. ${ }^{16}$

Using the Chi-squared test, the bivariate analysis results for snacking habits and BMI showed that snacking habits did not significantly correlate to obesity. This finding was in line with a study that Spanos and Hankey conducted on university students in Greece and Scotland, which revealed that there was no significant correlation between BMI and snacking habits. ${ }^{17}$ However, that study's finding was not in line with the study conducted by Majeed on students at Dammam University in Saudi Arabia and a study by Lani et al. on subjects aged 9-12 years, which found a correlation between snacking habits and BMI. ${ }^{18,19}$

Nowadays, snacking cannot be separated from lifestyle habits. The consumption of snacks increased from $74 \%$ in $1977-1978$ to $98 \%$ in $2003-2006 .{ }^{20}$ The types of snack that are frequently consumed are those that are high in calories and low in fiber. This trend is also followed by the consumption of large portions and sedentary behavior that might cause obesity in children. ${ }^{21}$

Table 3. Correlation between snacking habits and obesity indicator $(n=170)$.

\begin{tabular}{lcccc} 
Snacking habits & \multicolumn{2}{c}{ Obesity indicators } & Total n (\%) & P \\
& Non-obese F (\%) & Obese F (\%) & & \\
Rarely & $75(84.3 \%)$ & $14(15.7 \%)$ & $89(100 \%)$ & 0.62 \\
Frequently & $65(80.2 \%)$ & $16(19.8 \%)$ & $81(100 \%)$ & 0.62 \\
\hline Total & $140(82.4 \%)$ & $30(17.6 \%)$ & $170(100 \%)$ & 0.62 \\
\hline
\end{tabular}

Table 4. Correlation between eating habits and obesity indicator $(n=170)$.

\begin{tabular}{lcccc} 
Eating habits & \multicolumn{2}{c}{ Obesity indicators } & Total n (\%) & P \\
Non-obese F (\%) & Obese F (\%) & & 0.11 \\
Unhealthy & $46(75.4 \%)$ & $15(24.6 \%)$ & $101(100 \%)$ & 0.11 \\
Healthy & $94(86.2 \%)$ & $15(13.8 \%)$ & $109(100 \%)$ & 0.11 \\
\hline Total & $140(82.4 \%)$ & $30(17.6 \%)$ & $1700 \%)$ & \\
\hline
\end{tabular}

Table 5. Correlation between physical activity and obesity indicator $(n=170)$

\begin{tabular}{lcccc} 
Physical activity & \multicolumn{2}{c}{ Obesity indicators } & Total n (\%) & P \\
& Non-obese F (\%) & Obese F (\%) & & \\
$\leq 3$ days/week & $104(83.2 \%)$ & $21(16.8 \%)$ & $125(100 \%)$ & 0.79 \\
$>3$ days/week & $36(80 \%)$ & $9(20 \%)$ & $45(100 \%)$ & 0.79 \\
\hline Total & $140(82.4 \%)$ & $30(17.6 \%)$ & $170(100 \%)$ & 0.79 \\
\hline
\end{tabular}


Snacking habits enable the body to gain additional energy, without realizing that the energy intake exceeds the body's need and eventually causes fat accumulation. This kind of habit will can also result in obesity in children.

In this study, the absence of a correlation between snacking habits and obesity might be due to sociocultural differences and differences in what constitutes healthy behavior. Snacking before feeling hungry will increase the diet quantity in children, which then affects their BMI. ${ }^{6}$ Snacking habits did not correlate to BMI. Although total daily energy was associated with nutritional status, snacking only accounted for $10-20 \%$ of the daily total energy needs. Therefore, excessive snacking did not correlate to the total daily intake. ${ }^{22}$ Furthermore, the analysis of eating habits and BMI using the Chi-squared test also showed no significant correlation between these two variables. This finding was in line with a study conducted by Al Muammar et al. on adolescents aged 12-15 years in Riyadh, Saudi Arabia, a study by Benazeera and Chauhan on subjects aged 14 and 15 years, and a study by Mahmoud and Taha on nursing students at Benha University. These three studies showed no significant correlation between eating habits and BMI. ${ }^{12,23,24}$

However, a study conducted by Wulandari et al. on adolescents aged 15-17 years found that eating habits were significantly correlated to obesity. ${ }^{25}$ Another study showed that obesity was associated with many lifestyle factors, such as eating unhealthy foods, and this also played an important role in creating an obesogenic environment. ${ }^{26}$

In this study, adolescent BMI was not related to eating habits. The absence of a correlation between eating habits and the obesity indicator was possible because BMI was not the only factor that was influenced by eating habits; many other factors contributed to BMI. Chronic disease, which might affect an individual's physical condition and eating habits, could also influence BMI. ${ }^{27}$ Moreover, socio-economic status can influence BMI because it can affect the purchasing power required to meet a person's nutritional needs.

The bivariate analysis using the Chi-squared test for the relationship between physical activity and BMI also showed no significant correlation between these two variables. This finding is in line with a study conducted by Cruz et al. on adolescents aged 1418 years, which showed no correlation between physical activity and BMI. ${ }^{28}$ However, the findings in this study are not in line with a study conducted by Keykhaei et al. on children aged 7-11 years in Zahedan, Iran, and a study conducted by Krismawati et al., on teens in middle- and late-adolescence, which found a significant correlation between physical activity and BMI. ${ }^{29,30}$

According to Sartika, physical activity is the main cause of obesity in Indonesia, especially for people with a low level of physical activity. ${ }^{31}$ Thus, lack of physical activity is the main factor because it can affect the balance between the energy that is produced and released, which then causes obesity. ${ }^{32}$ An analysis by Mustelin found that children who performed less physical activity had a 1.35-times greater risk of obesity than those who frequently engaged in physical activity. ${ }^{33}$

In the present study, no significant correlation was found between physical activity and BMI, possibly because BMI was not solely influenced by physical activity. BMI is influenced by many other factors, such as the level of education, knowledge, and socioeconomic status that affect people's lifestyle habits and daily activity levels, which eventually influence their BMI. ${ }^{34}$ Environmental factors also affect the level of physical activity. A study showed that children who lived in an urban area had a 1.2-times greater chance of being obese than children who lived in a rural area. A sedentary lifestyle, such as watching TV and playing video games or spending time on the computer, also result in less physical activity, and people with these habits tend to be obese. This is in line with a study that stated that the physical activity had a slight impact $(0.1 \%)$ on BMI, while other factors had a greater impact $(99.9 \%) .{ }^{35}$

In general, the findings in our study have shown that having a healthy lifestyle helps prevent the development of NCDs. However, a number of the study's respondents were overweight and obese. In the future, a study that aims to develop interventions to raise awareness about the risks of NCDs focusing on weight control is recommended.

Correspondence: Hening Pujasari, Department of Basic Science and Fundamentals of Nursing, Faculty of Nursing, Universitas Indonesia, Jalan Prof. Dr. Bahder Djohan, UI Depok Campus, West Java 16424, Indonesia.

Tel. +62 78849120 - Fax: +62.7864124. E-mail: pujasari@ui.ac.id

Key words: Adolescents; eating habits; Indonesia; NCDs; obesity; physical activity; snacking habits.

Contributions: IL, Concept and design, analysis, and interpretation of data, drafting revision of manuscript, final approval; HP, K, supervised conceptualization and design study, revising it critically, final approval.

Conflict of interest: The authors declare that they have no conflict of interest.

Acknowledgments: We would like to thank the Direktorat Riset \& Pengembangan Universitas Indonesia for supporting this study through PUTI Prosiding Universitas Indonesia 2020 (NKB3430/UN2.RST/HKP05.00/2020). We are also grateful to all high school students in Jakarta who had participated as respondents of the study.

Institutions where the research was carried out: The data in this study were distributed online through various social media to all high schools in Jakarta Province.

Ethics approval and consent to participate: This study has been approved by Ethics Committee of Faculty of Nursing Universitas Indonesia, Depok with the number: SK-219/UN2.F12.D1.2.1/ ETIK.2020. The respondents that participated in this research also have filled in the informed consent form.

Availability of data and materials: The data and material in this study are available from the corresponding author on reasonable request.

Conference presentation: This final manuscript has been presented at $7^{\text {th }}$ Virtual Biennial International Nursing Conference, Faculty of Nursing, Universitas Indonesia on September $24^{\text {th }}$, October $30^{\text {th }}$, November $16^{\text {th }} 2020$.

Received for publication: 14 August 2020.

Accepted for publication: 7 May 2021.

o Copyright: the Author(s), 2021

Licensee PAGEPress, Italy

Journal of Public Health Research 2021; $10($ s1):2402

doi:10.4081/jphr.2021.2402

This work is licensed under a Creative Commons Attribution NonCommercial 4.0 License (CC BY-NC 4.0). 


\section{References}

1. World Health Organization. 10 facts on obesity. Geneva: World Health Organization. 2017. Available from: https://www.who.int/features/factfiles/obesity/en/.

2. Sugiatmi, Handayani DR. [Faktor dominan obesitas pada siswa sekolah menengah atas di Tangerang Selatan Indonesia (the dominant factors of obesity on high school students in South Tangerang, Indonesia)].[Article in Indonesian]. Jurnal Kedokteran dan Kesehatan 2018;14:1-10.

3. Ministry of Health, Republic of Indonesia. [Riset Kesehatan Dasar 2018 (basic health research 2018)].[in Indonesian]. Jakarta: Institute for Health Research and Development; 2019.

4. Ogden CL, Flegal KM. Changes in terminology for childhood overweight and obesity. Natl Health Stat Report 2010;25:1-5.

5. Kurdanti W, Suryani I, Syamsiatun NH, Siwi LP, et al. [Faktorfaktor yang mempengaruhi kejadian obesitas pada remaja (factors affecting to obesity on adolescences)].[Article in Indonesian]. Jurnal Gizi Klinik Indonesia 2015;11:179-90.

6. Nuryani N, Rahmawati R. [Kebiasaan jajan berhubungan dengan status gizi siswa anak sekolah di Kabupaten Gorontalo (snacking to nutrition status on elementary students in Gorontalo District)].[Article in Indonesian]. Jurnal Gizi Indonesia 2018;6:114-22.

7. Candrawati S. [Hubungan tingkat aktivitas fisik dengan indeks massa tubuh (IMT) dan lingkar pinggang mahasiswa (the correlation between physical activities with body mass index and waist size of the students of a university)].[Article in Indonesian]. Jurnal Keperawatan Soedirman 2011;6:112-8.

8. Ho-Pham LT, Lai TQ, Nguyen MTT, Nguyen TV. Relationship between body mass index and percent body fat in Vietnamese: implications for the diagnosis of obesity. PLoS One 2015;10: $\mathrm{e} 0127198$

9. Neuhouser ML, Lilley S, Lund A, Johnson DB. Development and validation of a beverage and snack questionnaire for use in evaluation of school nutrition policies. J Am Diet Assoc 2009;109:1587-92.

10. Ministry of Education and Culture, Republic of Indonesia. [Data pokok Pendidikan (education main data)].[in Indonesian]. Jakarta: Ministry of Education and Culture; 2019. Available from: https://dapo.dikdasmen.kemdikbud.go.id/

11. Fayasari A, Julia M, Huriyati E. [Pola makan dan indikator lemak tubuh pada remaja (diet and body fat index on adolescents)].[Article in Indonesian]. Jurnal Gizi Indonesia 2018;7:15-21.

12. Benazeera, Chauhan UJ. Association between eating habits and body mass index (BMI) of adolescents. Int J Med Sci Public Health 2014;3:940-3.

13. Puspadewi RH, Briawan D. [Persepsi tentang pangan sehat, alasan pemilihan pangan dan kebiasaan makan sehat pada mahasiswa (university students' perception on healthy food, reasons, and healthy diet)].[Article in Indonesian]. Jurnal Gizi dan Pangan 2014;9:211-8.

14. Thamrin MH, Kusharto CM, Setiawan B. [Kebiasaan makan dan pengetahuan reproduksi remaja putri peserta pusat info dan konseling kesehatan reproduksi remaja (PIK-KRR) (diet and knowledge on reproductive health on female adolescents as the participants of information center and adolescents' reproductive health counseling)].[Article in Indonesian]. Jurnal Gizi dan Pangan 2008;3:124-31.

15. Novitasary MD. [Hubungan antara aktivitas fisik dengan obesitas pada wanita usia subur peserta jamkesmas di puskesmas Wawonasa Kecamatan Singkil Manado (relationship between physical activities and obesity on women of childbearing age as the participants of community health insurance in Wawanosa health center in Singkil district, Manado)].[Article in Indonesian]. Jurnal e-Biomedik 2013;1:1040-6.

16. Turege JN, Kinasih A, Kurniasari MD. [Hubungan antara aktivitas fisik dengan obesitas di puskesmas Tegalrejo, Kota Salatiga (relationship between physical activities and obesity in Tegalrejo health center, Salatiga)].[Article in Indonesian]. Jurnal Ilmu Keperawatan dan Kebidanan 2019;10:256-63.

17. Spanos D, Hankey CR. The habitual meal and snacking patterns of university students in two countries and their use of vending machines. J Hum Nutr Diet 2010;23:102-7.

18. Majeed F. Association of BMI with diet and physical activity of female medical students at the University of Dammam, Kingdom of Saudi Arabia. J Taibah Univ Med Sci 2015;10:188-96.

19. Lani A, Margawati A, Fitranti DY. Hubungan frekuensi sarapan dan konsumsi jajan dengan z-score IMT/U pada siswa sekolah dasar (relationship between the frequency of having breakfast and snacking with z-score IMT/U on elementary school students). Journal of Nutrition College 2017;6:277-84. Bahasa Indonesia

DOI: https://doi.org/10.14710/jnc.v6i4.18250.

20. Piernas C, Popkin BM. Trends in snacking among U.S. children. Health Aff (Millwood) 2010;29:398-404. DOI: 10.1377/hlthaff.2009.0666.

21. Frazão E, Stewart H, Hyman J, Carlson A. Gobbling up snacks: cause or potential cure for childhood obesity? Washington, DC: Economic Research Services U.S. Department of Agriculture; 2012. Available from: https://www.ers.usda.gov/amber-waves/2012/december/gobbling-up-snacks-cause-or-potential-cure-for-childhood-obesity/

22. Karmila, Fayasari A. [Kecukupan asupan, kontribusi selingan dan obesitas pada siswa SMP di Jakarta Timur (nutrition intake adequacy, snacking, and obesity on junior high school students in East Jakarta)].[Article in Indonesian]. Binawan Student J 2019;1:50-7.

23. Al-Muammar MN, El-Shafie M, Feroze S. Association between dietary habits and body mass index of adolescent females in intermediate schools in Riyadh, Saudi Arabia. East Mediterr Heal J 2014;20:39-45.

24. Mahmoud MH, Taha AS. The association between eating habits and body mass index among nursing students. J Nurs Health Sci 2017;6:14-26.

25. Wulandari S, Lestari H, Fachlevy AF. [Faktor yang berhubungan dengan kejadian obesitas pada remaja di SMA Negeri 4 Kendari tahun 2016 (Factors affecting to obesity on adolescents of SMA Negeri 4 in Kendari year 2016)].[Article in Indonesian]. Jurnal Ilmiah Mahasiswa Kesehatan Masyarakat 2016;1:1-13.

26. Manggabarani S, Hadi AJ, Ishak S. [Edukasi aktivitas fisik dalam pencegahan obesitas di Madrasah Tsanawiyah Aisyiyah Kota Binjai (Education on physical activity in preventing obesity at Madrasah Tsanawiyah Aisyiyah Kota Binjai)].[Article in Indonesian]. Jurnal Pengabdi Masyarakat Ilmu Kesehatan 2020;1:1-7.

27. Speroff L, Marc A. Clinical endocrinology and fertility. 8th ed. Philadelphia: Lippincott Williams \& Wilkins; 2010.

28. Cruz C, Sequeira S, Gomes H, Pinto D, et al. Relationship between physical fitness, physical activity and body mass index of adolescents. BMJ Sports Med 2011;45:A8-A9.

29. Keykhaei F, Shahraki M, Sargolhosseinzadeh E, Shahraki T, et al. Correlation of body mass index and physical activity among 7- to 11-year children at Zahedan, Iran. Food Nutr Bull 
2016;37:364-74.

30. Krismawati LDE, Andayani NLN, Wahyuni N. The relationship between physical activities and body mass index (BMI) in adolescents aged 16-18 years old in SMA Negeri 2 Denpassar. Majalah Ilmiah Fisioterapi Indonesia 2019;7:29-32.

31. Sartika RAD. Faktor risiko obesitas pada anak 5-15 tahun di Indonesia (risk factors of obesity on children aged between 5 to 15 in Indonesia)].[Article in Indonesian]. Makara Kesehatan 2011;15:37-43.

32. Christianto DA. [Hubungan aktivitas fisik terhadap kejadian obesitas berdasarkan indeks massa tubuh di Desa Banjaroyo (the relationship between physical activities and obesity according to body mass index in Banjaroyo village, Kulon Progo, Yogyakarta)].[Article in Indonesian]. Berkala Ilmiah Kedokteran Duta Wacana 2018;3:78-88.
33. Mustelin L, Silventoinen K, Pietiläinen K, et al. Physical activity reduces the influence of genetic effects on BMI and waist circumference: a study in young adult twins. Int J Obes (Lond) 2009;33:29-36. DOI: 10.1038/ijo.2008.258.

34. Suryaputra K, Nadhiroh SR. [Perbedaan pola makan dan aktivitas fisik antara remaja obesitas dengan non obesitas (the differences on diet and physical activities between obese and nonobese adolescents)].[Article in Indonesian]. Makara Kesehatan 2012;16:45-50.

35. Ramdani R, Jajat, Sutisna N, Sudrazat A, et al. [Aktivitas fisik dan body mass index pada anak usia dini: pengukuran METs dengan accelerometer ActivPAL (physical activities and body mass index on toddlers: METs measurements with ActivPAL accelerometer)].[Article in Indonesian]. Jurnal Keolahragaan 2019;5:45-52. 